\title{
ACRL honors the 2018 award winners, part 1 \\ A recognition of professional development
}

\section{Larry P. Alford wins Hugh C. Atkinson Memorial Award}

Larry P. Alford, chief librarian at the University of Toronto, has been named the 2018 winner of the Hugh C. Atkinson Memorial Award. Alford will receive a cash award and citation during the ACRL President's Program June 23, 2018, at the ALA Annual Conference in New Orleans.

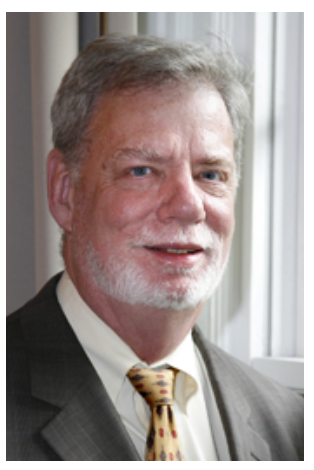

Larry P. Alford
Named in honor of one of the pioneers of library automation, the Atkinson Award recognizes an academic librarian who has made significant contributions in the area of library automation or management and has made notable imservices or research.

"The committee selected Larry P. Alford because of his distinguished career as an academic librarian, including his outstanding experience in library automation and library management, as well as his demonstrated risk taking in redesigning library spaces and securing funding for renovations," said Theresa S. Byrd, Hugh C. Atkinson Memorial Award committee chair and dean of the Copley Library at the University of San Diego. "As chair of the OCLC Board, Larry focused on technol- ogy, and he is currently involved with linked data, digital preservation, entrepreneurship, and research data management projects.

"Additionally, throughout his library career, Larry has increased money for collections and championed public service initiatives," continued Byrd. "He believes in nurturing new library professionals and has served as a mentor in both the Northern Exposure to Leadership Initiative and the Senior Fellow Program at UCLA. Larry's colleagues in both Canada and the United States spoke of his collaborative spirit within the libraries he worked and with external library partners. He has numerous publications, presentations, and extensive professional and university service. Larry, an innovator and visionary, epitomizes what Hugh C. Atkinson represented to our profession."

The Hugh C. Atkinson Award is jointly sponsored by four ALA divisions: ACRL, the Association for Library Collections and Technical Services, the Library Leadership and Management Association, and the Library and Information Technology Association. The award is funded from an endowment established to honor Atkinson.

Chase Ollis is ACRL program officer, email: collis@ala.org (C) 2018 Chase Ollis 


\section{David W. Lewis named Academic/Research Librarian of the Year}

David W. Lewis, dean of the Indiana University-Purdue University Indianapolis (IUPUI) University Library, is the ACRL Academic/ Research Librarian of the Year. The award, sponsored by GOBI Library Solutions from EBSCO, recognizes an outstanding member of the library profession who has made a significant national or international contribution to academic/research librarianship and library development.

Lewis will receive a \$5,000 award during the ACRL President's Program at the ALAAnnual Conference.

"David Lewis is a visionary in academic libraries, and he has shared his vision widely over an illustrious career," said Jennifer L. Fabbi, chair of the ACRL Academic/Research Librarian of the YearAward Committee and dean of the California State UniversitySan Marcos University Library. "The award committee noted that David has been inclusive in his leadership and service, which has benefited academic librarianship at many levels."

"The past recipients of this award include many librarians I have looked up to and admired throughout my career,' Lewis said. "Joining their company is an exceptional honor.You like to think that the work you are doing is making a difference, but it is often hard to know.To receive this recognition is a wonderful affirmation.I am at once surprised and deeply grateful."

Celebrated as a champion of disruption, Lewis' decades-long career as an academic library leader has been characterized by a record of accomplishments in the areas of academic technologies, digital humanities, open access to scholarly and educational resources, library integration into campus and community life, and innovative service development. Through his leadership, the IUPUI University Library has developed a model program of digitally disseminating unique scholarship, data, and artifacts created by university faculty, students, and community partners.

"David Lewis epitomizes the academic and research library profession's commitment to transforming higher education and the scholarly communication landscape," noted ACRL Executive Director Mary Ellen K. Davis."He has long been a leader in the open access and digital scholarship movements, as well as advocating for the adoption of new technologies in libraries and higher education."

Lewis' extensive record of publications, presentations, and professional service ranges across the future of library collections, library space, the library and open access, scholarly communication, and provocative thinking about the future of the academic library. His book Reimagining the Academic Library (2016) represents a culmination of decades of leadership in thinking about how new and disruptive technologies require a major shift in the ways academic libraries and librarians go about their work. His 1988 article "Inventing the Electronic University" was selected as one of seven landmark articles to be reprinted in the 75th anniversary special issue of College \& Research Libraries in 2015.

Prior to becoming dean of the University Library in 2000, Lewis served in a variety of leadership positions at IUPUI including deputy university librarian (1998-99), associate executive director of university libraries (1996-98), and head of public services (1993-96). His work prior to joining IUPUI includes serving as head of the Research and Information Services Department at the University of Connecticut (1988-93) and Lehman Librarian at the Columbia University Herbert H.Lehman Library (1983-88). 


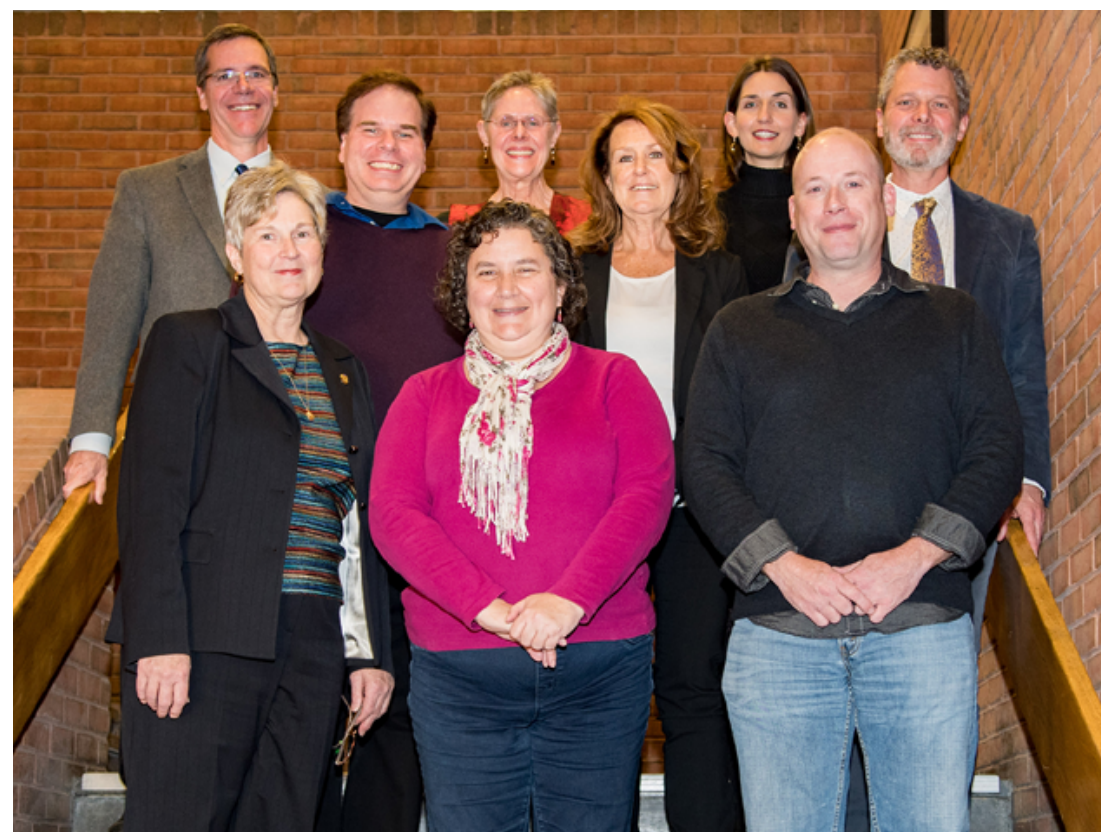

Front row (left to right): Georglyn Davidson, Margaret Montet, and Damon Hunnicutt. Second row (left to right): Michael Babij, Regina Hierholzer, and Bill Hemmig. Third row (left to right): Karl Carter, Maureen McCreadie, and Jacqueline Burger of Bucks County Community College.

\section{Bucks County Community College Program wins CJCLS/EBSCO Community College Learning Resources Award}

Bucks County Community College has been chosen to receive the 2018 Community and Junior College Libraries Section EBSCO Community College Learning Resources Award for its Learning Resources Faculty Institutes program.

The $\$ 750$ award and plaque, donated by EBSCO Information Services, will be presented to Bucks County Community College Dean of Learning Resources and Online Learning Bill Hemmig at the ALA Annual Conference.

The Learning Resources Faculty Institutes are two- or four-day immersive professional development opportunities for Bucks County Community College faculty. Designed and convened by faculty for faculty, the institutes, for which participants receive a stipend, prepare faculty for integrating infor- mation and multimedia literacy instruction into their courses and assignments, creating accessible course content, providing wellinformed and effective academic advising, effectively teaching in a web-conferenced multicampus format, and redesigning courses through the adoption of open educational resources.

"Bucks County Community College learning resources faculty have shown strong leadership in their participation in these institutes," said Award Chair Sandy McCarthy of Washtenaw Community College.

"These multidisciplinary professional development programs have expanded over the years from one institute in 2008 to an expanded selection on a variety of topics, including their first institute on open educational resources for the summer of 2018. The learning resources faculty are to be commended for their efforts in providing excellent opportunities to educate the educators." 


\section{Collard named EBSS Distinguished Librarian}

Scott A. Collard, head of specialized research services at New York University, is the recipient of the Education and Behavioral Sciences Section (EBSS) Distinguished Education and Behavioral Sciences Librarian Award.

This award honors a distinguished academic librarian who has made an

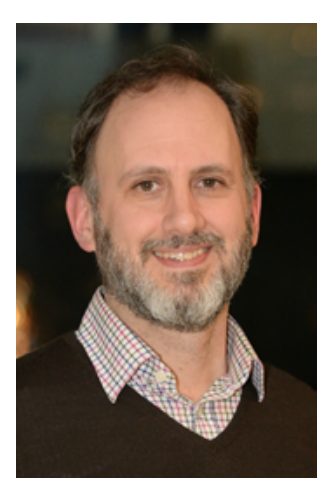

Scott A. Collard outstanding contribution as an education and/or behavioral sciences librarian through accomplishments and service to the profession.

A plaque will be presented to Collard during an EBSS event at the ALA Annual Conference.

"With his record of service to EBSS, his ability to bring diverse perspectives together for the good of the whole, and his substantial contributions to the profession, the committee is thrilled to name Scott Collard as the recipient of the EBSS Distinguished Librarian Award for 2018," said award chair Stephanie Davis-Kahl, scholarly communications librarian at Illinois Wesleyan University. "As a past-chair of the section and a member of several committees within EBSS, Scott has demonstrated a high level of collegiality and leadership."

Davis-Kahl continued, "As Nancy O'Brien stated in her nomination letter, 'When working with Scott there is the assurance that he draws everyone into the conversation, listens to the various viewpoints, and will develop a plan or program based on consensus. His leadership abilities are exceptional, and he is thoughtful of individual perspectives while keeping the long-term goals in mind.

As a leader in EBSS, Scott recognizes the shared values of the education and behavioral sciences community within the section, encourages innovation and collaboration, and offers opportunities to engage in group projects within the section as well as across sections, such as the 2014 program cosponsored with ANSS.' We congratulate Scott on this achievement, with gratitude for his dedication."

\section{Dysert named ESS De Gruyter Grant winner}

Anna Dysert, cataloger librarian at McGill University, has been selected to receive the European Studies Section De Gruyter European Librarianship Study Grant for her project "A Survey of the Manuscripts of Isaac Israeli: The Transmission and Transformation of 12thCentury Medicine."

S p o n s o r e d by the Walter de Gruyter Foundation for Scholarship

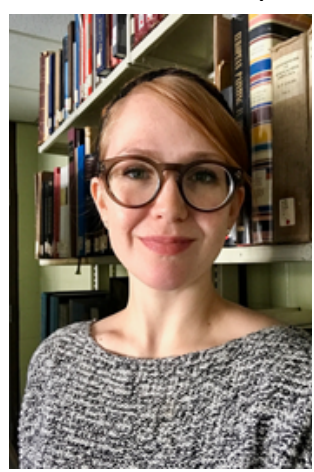

Anna Dysert and Research, the grant provides $€ 2,500$ to support a trip to Europe. The primary criterion for awarding the grant is the significance and utility of the proposed project as a contribution to the study of the acquisition, organization, or use of library resources from or relating to Europe.

Dysert will receive the award check during the ALA Annual Conference.

Dysert's project focuses on a survey of the 12th- and 13th-century manuscripts of Isaac Israeli's "Dietae universals" and "Dietae particulares," an influential yet understudied medical treatise of the 12thcentury renaissance. The project involves the identification, dating, localization, and creation of detailed paleographical and codicological description of the manuscripts containing these texts.

"Dysert's ambitious yet eminently executable, focused, and well-articulated proposal promises to accomplish several things simultaneously as a result of a 30-day 
resource sojourn in Germany," said award cochairs Katie Gibson of Miami University and Thomas Keenan of Princeton University. "She targets a small complex of relevant manuscripts held in four German repositories and lays out a plan for their analysis via specific codicological and paleographic methods. This analysis has a narrower aim of re-contextualizing a manuscript held at Dysert's home institution (McGill University's Osler Library of the History of Medicine) and a broader objective to illuminate an u n d e r explored aspect of the as similation and dissemination of medical thought and practice of A r a b i c

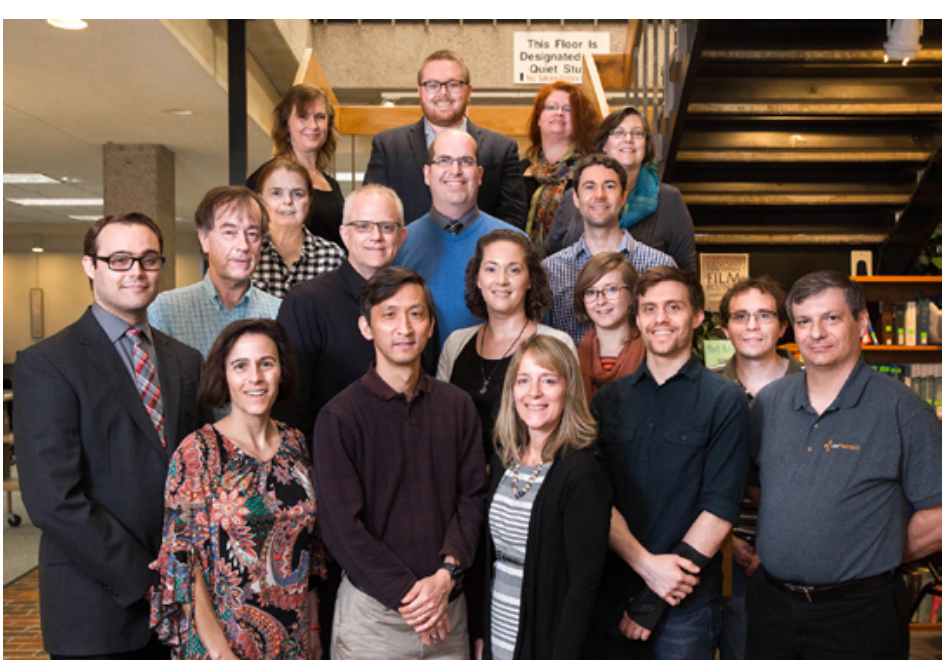

SUNY-Geneseo Library staff.
Traurig Library, Waterbury, Connecticut; State University of New York (SUNY), College at Geneseo Milne Library, Geneseo, New York; and Virginia Commonwealth University (VCU) Libraries, Richmond, Virginia. Sponsored by ACRL and GOBI Library Solutions from EBSCO, the award recognizes the staff of a college, university, and community college library for programs that deliver exemplary services and resources to further the educational origin in Europe in the late Middle Ages.

"Dysert's formal training in codicology, paleography, and Western history, her experience as a professional librarian in a library of medical history, and her strong publishing record in library science and history of science encourage hopes that the expedition funded by the De Gruyter award will prove a highly productive one," continued Gibson and Keenan. "We and the other members of the ACRL European Studies Section Award Committee are exceptionally pleased to be able to offer the award to Ms. Dysert this year."

\section{Excellence in Academic Libraries Award winners}

The recipients of the 2018 Excellence in Academic Libraries Award are Naugatuck Valley Community College (NVCC) Max R. said ACRL Executive Director Mary Ellen K. Davis. "This year's winners demonstrate a clear commitment to student success, an entrepreneurial mindset that results in innovative programs, an engagement with the local and campus communities, and leadership in scholarly publishing. Receiving an Excellence in Academic Libraries Award is a tribute to each library and its staff for outstanding services, programs, and leadership."

NVCC's Max R. Traurig Library, winner in the community college category, impressed the award committee with its unique services and partnerships.

"The wealth of innovation taking place at the Traurig Library, such as circulating guitars, their revision of instruction based on assessment, and their close partnerships with high schools for student transi- 


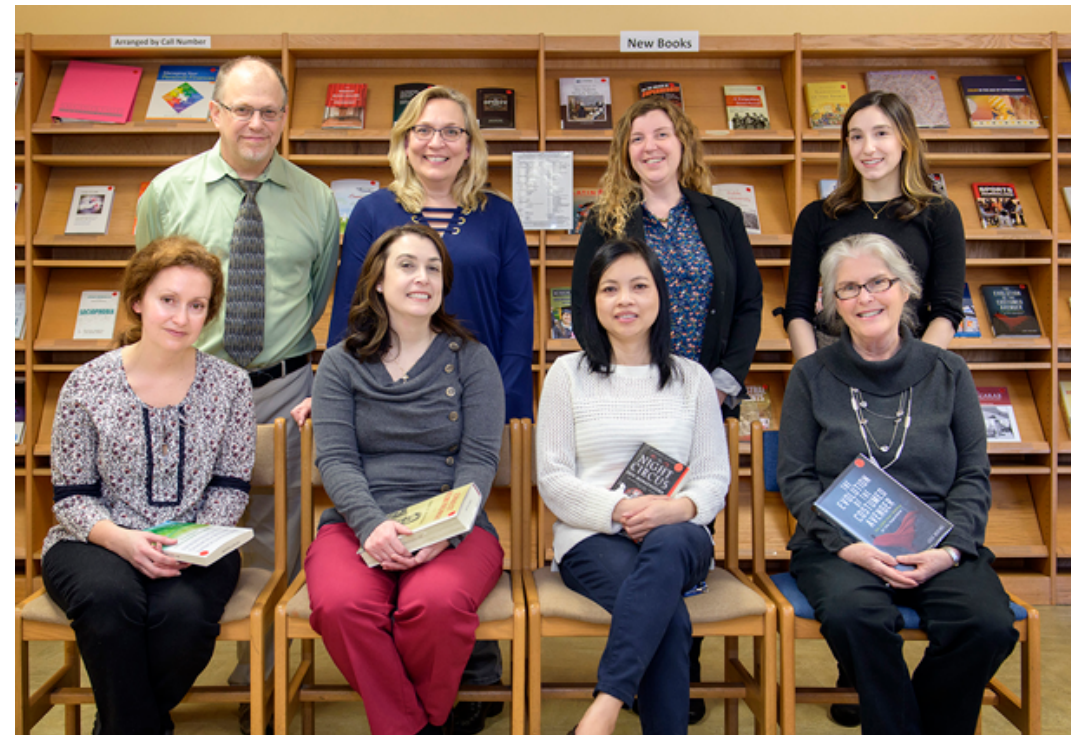

Naugatuck Valley Community College Max R. Traurig staff.

ings from

AiA, NVCC

librarians

partnered with school librarians at area high schools to develop an information literacy instruction program for high school students. Students reported increased confidence

tion and achievement, set them apart as forward-thinking and student-focused," said Ann Campion Riley, chair of the 2018 in researching and demonstrated improved ability to integrate information sources into research projects.

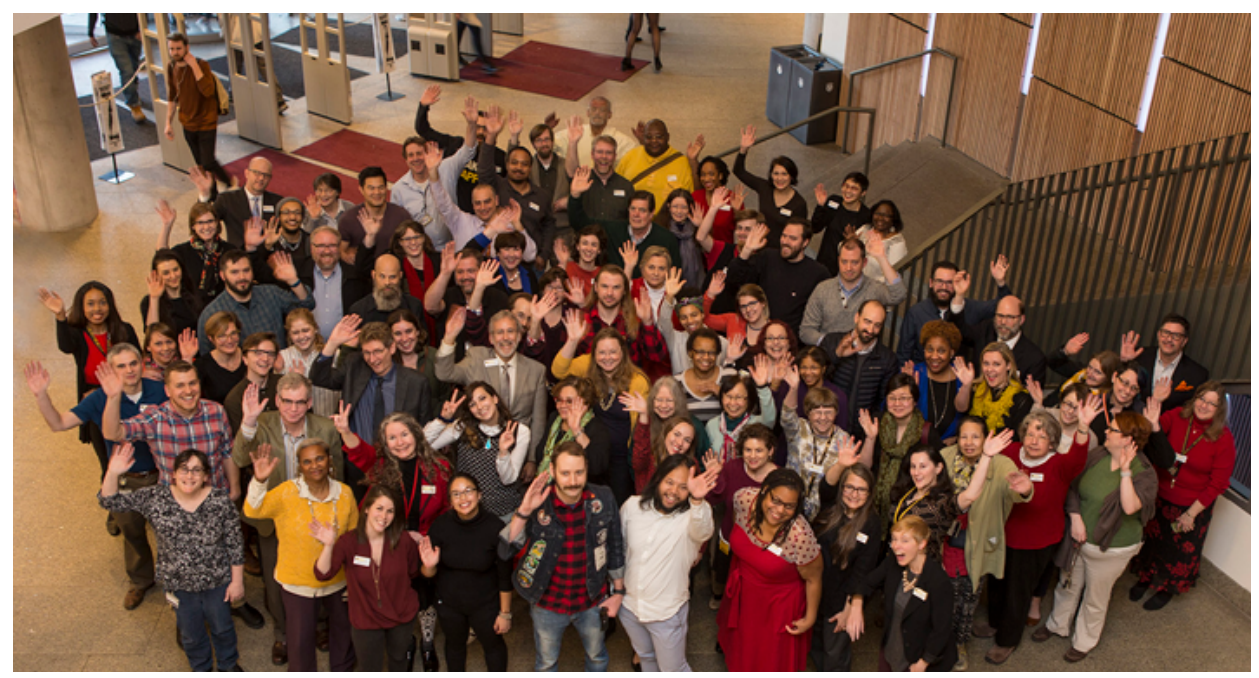

Virginia Commonwealth University Libraries staff.

Excellence in Academic Libraries Awards Committee and vice provost and university librarian at the University of Missouri.

The library's participation in the ACRL Assessment in Action (AiA) program in 2014-15 led to an evolution in its first-year experience and information literacy instruction programs. As a result of their find-
"The staff of the Max R. Traurig Library are thrilled and honored to be recognized with this prestigious award" said Jaime Hammond, director of library services at NVCC. "The mission and vision of our institution has been the inspiration for all of the work that we do. We are grateful to our president for all of her support, and to the 
students, staff, and faculty of our campus for being amazing partners."

SUNY-College at Geneseo, winner of this year's award in the college category, was chosen for its programming and outreach efforts.

"A strong commitment to open access to scholarship and educational resources, their Summer Library Research Academy, and work with local high schools, along with great partnerships and inspiring letters of support from across their community, highlighted the strength of the Milne Library's programs and outreach," noted Riley.

In their Access Opportunity Programs (AOP) Summer Library Research Academy, SUNY-Geneseo research and instruction librarians work to acclimate incoming first-year students to the rigors of college and familiarize them with the library's resources and services. The program, a four-week crash course in college-level research skills, includes a library scavenger hunt, annotated bibliography, collaborative research paper, and poster session. The AOP Summer Library Research Academy received the 2016 ALA Library Instruction Round Table Innovation in Instruction Award.

"We were very excited, humbled, and honored to hear from ACRL President Cheryl Middleton that we were chosen to receive this award," said Ben Rawlins, library director at SUNY-Geneseo. "It is a testament to the dedication, creativity, innovation, and collaborative efforts of our staff to think creatively through initiatives like the IDS Project, SUNY OER Services, and the Library Instruction Leadership Academy. Thank you for this recognition."

The VCU Libraries, winner in the university category, was selected for its transformative services, initiatives, and role within the campus community.

"From their many events and partnerships to scholarly publishing and information literacy initiatives and a strong commitment to the arts, along with their innovative digital history and data management projects, the VCU Libraries demonstrate exemplary planning and actions that contribute to the library's central role in the work of the university," said Riley.

Among the libraries' numerous initiatives is the Scholarly Communications and Publishing Division, which supports VCU faculty, staff, and students in disseminating open scholarship. Its programs include the Open Access Author Publishing Fund to encourage publishing in open access journals; the "Mapping the KKK" digital humanities visualization project, in collaboration with VCU's history department; and the "Social Welfare History Project," a national online information portal documenting the social welfare movement's impact on the United States.

"We are deeply honored by this distinguished recognition from ACRL," said VCU University Librarian John E. Ulmschneider. "The faculty and staff of the VCU Libraries have worked with creativity, passion, and immense dedication to create an exemplary research library for the 21st century and to fulfill our mission of transforming our communities through our teaching, collections, and scholarship. This award is a powerful testament to the extraordinary effort of our staff in establishing the VCU Libraries as the preeminent destination at Virginia Commonwealth University for learning, research, and cultural dialogue. We are grateful for this recognition by our peers of the vitality of our libraries at the core of academic enterprise in all of its forms at VCU."

Each winning library will receive $\$ 3,000$ and a plaque, to be presented at an award ceremony held on each recipient's campus.

\section{Brager, Mars, and Pittman win IS Innovation Award}

Trent Brager, Amy Mars, and Kim Pittman have been selected to receive the 2018 Instruction Section Innovation award for their work on 23 Framework Things, a 
free online professional development opportunity that helps librarians engage

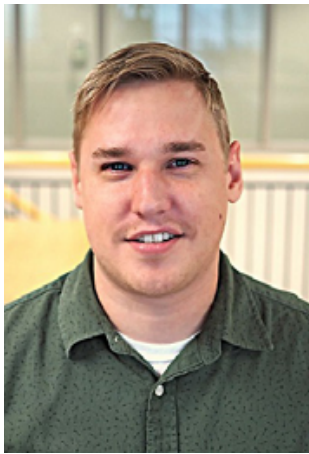

Trent Brager at their own pace through readings, activities, reflection, and discussion. Brager is education and social sciences librarian at the University of St. Thomas; Mars is research, instruction, and outreach librarian at St. Catherine University; and Pittman is information literacy and assessment librarian at the University of Minnesota-Duluth.

The annual award recognizes a project that demonstrates creative, innovative, or unique approaches to information literacy instruction or programming. The award consists of a plaque and a cash prize of $\$ 3,000$, donated by EBSCO Information Services.

23 Framework Things participants develop and share strategies with an

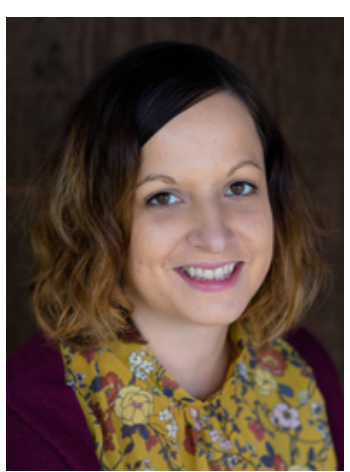

Amy Mars emerging online community of practice while earning prizes and badges. Each of the 23 Things addresses a different aspect of the ACRL Framework for Information Literacy for Higher Education (including metacognition, social justice, pedagogy, outreach/marketing, and assessment, among others) through resources such as readings, videos, or examples of the Framework in practice. The program provides an accessible entry point for librarians who want to learn more about the Framework but aren't sure where to start. Participants respond to the resources provided by writing a reflection or discussion post, creating or adapting a lesson plan, or identifying stakeholders or partners in order to apply what they have learned to their specific teaching role and/ or institutional context.

"The 23 Framework Things professional development program offers an innovative and open sourced solution to learning more about how to incorporate the Framework into information literacy instruction," said award committee chair Maoria J. Kirker of George Mason University. "The self-paced program allows users to interact with other librarians through commenting and reflection as they consider local implementation of the Framework. With the expansion beyond the Minnesota Library Association and an indefinite extension of the program, 23

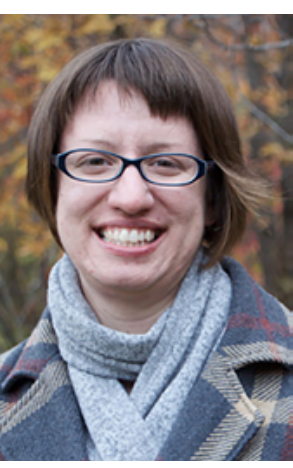

Kim Pittman
Framework Things is poised to help many librarians incorporate the Framework into their local context in the coming years."

Although originally created for use by Minnesota librarians, 23 Framework Things was made available to all interested participants in response to enthusiastic interest expressed by librarians outside the state. There are currently more than 300 registered participants from 42 states plus Washington, D.C., and Puerto Rico, along with nine countries outside of the United States.

\section{Nutefall receives IS Ilene F. Rockman Publication of the Year Award}

Jennifer E. Nutefall, university librarian at Santa Clara University, has been chosen as the winner of the Instruction Section Ilene F. Rockman Publication of the Year Award as editor of the book Service 
Learning, Information Literacy, and Libraries, published in 2016 by Libraries Unlimited. The award recognizes an outstanding publication related to library instruction published in the past two years.

The award, donated by Emerald Publishing, consists of a plaque and a cash

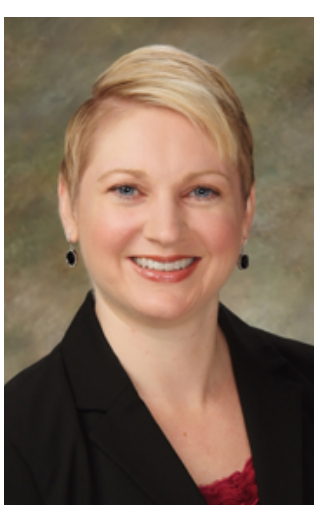

Jennifer E. Nutefall prize of $\$ 3,000$.

While service learning can be defined in many ways, for the context of this book it is defined as community service connected to a for-credit college course, providing students with opportunities to put what they learn into practice, to engage problem-solving skills, and to reflect on their experiences. Ideally, in-service learning course materials inform student service, and student experiences with service inform academic dialogue and comprehension. For many reasons, many colleges and universities include service learning requirements.

This book brings together a wide variety of contributors for chapters that provide a larger context for librarian involvement in service learning, the integration of theory and pedagogy, and practical examples of service learning partnerships.

Service Learning, Information Literacy, and Libraries covers a critical and emerging gap in information literacy literature," said Award Committee chair Maoria J. Kirker of George Mason University. "As many colleges and universities begin focusing on civic and community engagement, this book may act as a primer for librarians who wish to incorporate service learning into their practice. This timely book pushes the field in new directions as it encourages librarians to consider new and innovative methods of teaching information literacy concepts and skills."

\section{Scherlen named Marta Lange/ SAGE-CQ Press Award winner}

Allan Scherlen, professor and social sciences librarian at Appalachian State University, has been awarded the Politics, Policy, and International Relations Section Marta Lange/SAGE-CQ Press Award. The award, established in 1996, honors an academic or law librarian who has made distinguished contributions to bibliography and information service in law or political science.

S A G E - C Q Press, sponsor of the award, will present the $\$ 1,000$ award and

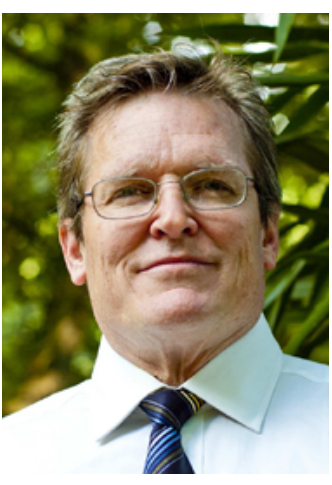

Allan Scherlen plaque to Scherlen during the ALA Annual Conference.

"In reviewing Scherlen's nomination, the committee was particularly impressed with his impact on the political science curriculum at Appalachian State University in being embedded in the undergraduate research methods course as well as his implementation of a two-year NEH grant dealing with Muslim culture and politics within the community," said award chair Julie Leuzinger, head of library learning services and political science librarian at the University of North Texas.

"The committee also noted that the nomination came from the chair of the department he serves. Scherlen's work touches on a number of the categories for award winners, including innovation in teaching and learning, scholarship and research, and civic engagement." $\not 2$ 